\title{
Pengaruh Kualitas Lingkungan dan Motivasi pada Kinerja Akademik Siswa SMA
}

\author{
Yudhistira Kusuma ${ }^{1}$, Hanson E. Kusuma ${ }^{2}$, Angela C. Tampubolon ${ }^{2}$, Tutin Aryanti ${ }^{3}$ \\ ${ }^{1}$ Program Studi Magister Arsitektur, SAPPK, Institut Teknologi Bandung. \\ ${ }^{2}$ Kelompok Keahlian Perancangan Arsitektur, SAPPK, Institut Teknologi Bandung. \\ ${ }^{3}$ Kelompok Keahlian Sejarah, Teori Arsitektur, dan Budaya Bermukim, FPTK, Universitas Pendidikan \\ Indonesia. \\ kusumayudhistira@yahoo.com
}

\begin{abstract}
ABSTRAK
Respons pengguna terhadap lingkungan dipengaruhi oleh lingkungan itu sendiri (faktor eksternal) dan atribut pengguna (faktor internal). Studi ini ingin melihat bagaimana kualitas lingkungan di SMA sebagai faktor eksternal dan motivasi siswa sebagai faktor internal mempengaruhi kinerja akademik siswa. Penelitian dilaksanakan dengan pendekatan kualitatif dan kuantitatif. Data dikumpulkan dengan survei menggunakan kuesioner daring. Dari analisis regresi, ditemukan kecenderungan bahwa dimensi faktor eksternal "keteraturan ruang kelas", "interaksi sosial dan pengawasan" dan "kualitas udara" lebih meningkatkan efektivitas belajar siswa daripada dimensi faktor internal "ketahanan dan peningkatan kemampuan". Sedangkan, penurunan kualitas udara, kebisingan, dan pencemaran lingkungan dapat menyebabkan gangguan belajar siswa. Berdasarkan temuan tersebut, dapat disimpulkan bahwa lingkungan belajar berperan penting dalam membentuk efektivitas belajar siswa.
\end{abstract}

Kata kunci: Efektivitas belajar, kinerja akademik, kualitas lingkungan SMA, respons siswa

\section{ABSTRACT}

Environment (external factors) and user attributes (internal factors) affect the user's response to the environment. This study aim to uncover how the quality of the environment in high school as an external factor and student motivation as an internal factor affects the academic performance of the students. The research was conducted with qualitative and quantitative approach. Data were collected by survey using an online questionnaire. From the regression analysis, it was found that the dimensions of external factors of "classroom order", "social interaction and supervision" and "air quality" further increased the effectiveness of student learning rather than internal dimensions of "resilience and capacity building". Meanwhile, the decrease of air quality, noise, and environmental pollution can cause student learning disruption. Based on these findings, it can be concluded that the learning environment plays an important role in shaping the effectiveness of student learning.

Keywords: Effectiveness of learning, academic performance, high school environment quality, students' response

\section{Pendahuluan}

Hubungan antara lingkungan dan respons manusia terjadi terus menerus karena manusia tidak bisa dipisahkan dari lingkungan. Berbagai studi telah mencoba melihat hubungan ini dari latar yang berbeda. Secara umum, karakteristik lingkungan tertentu memiliki efek yang berbeda pada manusia. Terdapat respons positif atau negatif yang 
muncul akibat karakteristik lingkungan. Respons positif atau negatif juga tergantung pada pengalaman dan pengetahuan yang dimiliki manusia.

Berbagai penelitian telah memberikan gambaran bahwa sikap atau perilaku manusia dapat dipengaruhi karakteristik lingkungan tertentu. Ellis (1965) sebagaimana dikutip oleh Suharyat (2009) menyatakan bahwa sikap dapat muncul karena adanya perasaan dan emosi. Emosi yang terdapat pada diri manusia menciptakan respons saat terdapat stimulus (objek) yang mengusik indra manusia, sehingga pada level tertentu berimplikasi pada tindakan. Menurut Suharyat (2009), sikap merupakan hasil dari pemikiran, perasaan, dan penilaian terhadap suatu objek berdasarkan pengalaman, keyakinan, dan gagasan sehingga menghasilkan kecenderungan untuk berperilaku. Objek yang dimaksud dapat berupa apa pun, bisa sesuatu yang kongkret maupun abstrak, termasuk lingkungan.

Lingkungan sekolah sangat erat hubungannya dengan proses belajar. Sebagai rutinitas dan kewajiban, secara normatif, siswa dituntut untuk pergi ke sekolah dengan tujuan utama untuk mengembangkan diri melalui belajar (Undang-undang No. 20 Tahun 2003 tentang Sistem Pendidikan Nasional, 2003) dan membangun kualitas diri untuk hidup dengan layak secara sosial (Darwin, 2010). Namun, pada prosesnya sering ditemukan beberapa kendala seperti kejenuhan dan hilangnya semangat yang dapat menurunkan kualitas proses belajar siswa (Slameto, 2010). Kendala-kendala tersebut dapat dipengaruhi oleh berbagai macam faktor, baik internal (siswa itu sendiri) maupun eksternal (lingkungan sekolah).

\section{Bahan dan Metode}

Belajar merupakan sebuah proses yang melibatkan hubungan antara stimulus dan respons (Berger \& Thompson, 1995); (Tucker \& Izadpanahi, 2017), sehingga terjadi internalisasi pengalaman baru yang dapat mengubah sikap dan perilaku manusia (Tucker \& Izadpanahi, 2017). Lingkungan sekolah sebagai sebuah medium untuk siswa beraktivitas memiliki peran penting dalam proses belajar (Sukmadinata, 2009). Lingkungan ini secara khusus diamati sebagai aspek eksternal yang mempengaruhi proses belajar siswa.

Pada penelitian ini, lingkungan sekolah dipilih karena merupakan sebuah latar yang kompleks, di mana di dalamnya terdapat berbagai dimensi, baik fisik maupun non fisik. Lingkungan fisik yang dimaksud melingkupi karakteristik bangunan, performa bangunan, dan lingkungan sekitar sekolah. Selain itu, sekolah juga merupakan lingkungan tempat terjadinya interaksi sosial antar pengguna. Oleh karena itu aspek sosial di sekolah akan ditinjau sebagai dimensi non fisik.

Selain faktor eksternal, terdapat faktor internal yang dapat mempengaruhi siswa dalam proses belajar. Faktor ini diasosiasikan dengan keadaan di dalam diri seseorang yang berkaitan dengan perasaan sebagai motor atau penggerak untuk melakukan kegiatan belajar. Menurut Koontz, Harold, O'Donell, \& Weihrich (2001) sebagaimana dikutip oleh Pujadi (2007), sebuah innerstate yang dapat mendorong, mengaktifkan, atau menggerakkan seorang manusia untuk melakukan sesuatu adalah motivasi. Berdasarkan definisi tersebut, perlu diketahui jenis motivasi seperti apa yang dapat mendorong siswa dalam proses belajar.

\subsection{Lingkungan Sekolah Secara Umum}

Sebagai lingkungan yang berperan penting dalam proses belajar (Sukmadinata, 2009), sekolah harus menjadi medium dengan kualitas lingkungan yang dapat menjamin keberhasilan belajar siswanya. Menguatkan opini tersebut, Rukmana \& Suryana (2006) serta Dalyono (2009) menyatakan bahwa kualitas sekolah turut menentukan tingkat 
keberhasilan ini. Segala aspek yang terdapat di dalamnya, baik fisik maupun non fisik berperan serta dalam mempengaruhi kinerja akademik para siswa.

Lingkungan sekolah didefinisikan sebagai sejumlah rangkaian fitur atau fasilitas yang ada pada sebuah sekolah dan membedakannya dari sekolah yang lain (Sobri, Hanum, Zulnaidi, \& Alfitri, 2017). Kualitas dari fitur dan fasilitas tersebut dapat mempengaruhi perilaku dari penggunanya, yaitu para guru/staf serta para siswa (Sobri, Hanum, Zulnaidi, \& Alfitri, 2017). Berdasarkan penjelasan tersebut, dapat disimpulkan bahwa tingkat kualitas proses belajar siswa tergantung dari kualitas lingkungan sekolah tempat mereka belajar.

\subsection{Lingkungan Fisik Sekolah}

Davison \& Lawson (2006) mendefinisikan lingkungan fisik sebagai segala jenis konteks fisik yang bersifat objektif (konkret), dapat dirasakan oleh manusia, serta memiliki dimensi rentang waktu untuk digunakan. Menurut Greenman (1988) sebagaimana dikutip oleh Ramli, Ahmad, Taib, dan Masri (2014), lingkungan fisik akan merefleksikan bagaimana manusia merasa, berpikir, dan berperilaku, sehingga secara tidak langsung mempengaruhi kualitas hidup manusia yang berada pada lingkungan tersebut.

Berdasarkan penjelasan di atas, lingkungan fisik sekolah dapat didefinisikan sebagai segala jenis objek yang dirasakan langsung oleh pengguna sekolah (khususnya siswa) serta dapat mempengaruhi kualitas belajarnya. Dalyono (2009) menyatakan bahwa berbagai aspek di sekolah seperti keadaan sekolah, fasilitas atau perlengkapan sekolah, kurikulum, dan kualitas guru, berpengaruh pada kualitas kinerja akademik siswa.

Berbagai studi telah membuktikan peran lingkungan fisik dalam membantu meningkatkan kualitas kinerja akademik. Kweon, Ellis, Lee, dan Jacobs (2017) menemukan bahwa jumlah pohon yang banyak di sekolah menjadikan lingkungan sekolah lebih sehat dan menjadikan siswanya lebih cakap di bidang matematika dan membaca. Temuan tersebut diperkuat oleh Hodson dan Sander (2017) yang menyatakan bahwa desain lanskap yang hijau dan asri pada konteks urban dapat meningkatkan kualitas membaca dan mendukung keberhasilan akademik.

Selain itu, kualitas lingkungan fisik juga dapat dinilai dari kinerja bangunan yang mendeskripsikan kualitas bangunan itu sendiri. Kinerja bangunan terkait dengan kenyamanan visual, kenyamanan termal, dan tingkat kebisingan. Studi yang dilakukan oleh Michael \& Heracleous (2017) menemukan bahwa pencahayaan alami adalah faktor yang sangat penting pada bangunan sekolah karena dapat meningkatkan produktivitas, lebih sehat, dan hemat energi. Sementara itu, dari aspek kenyamanan termal, studi mengatakan bahwa siswa lebih nyaman belajar pada kondisi suhu udara ruangan yang tidak teralu panas (Wang, et al., 2017) dengan merujuk kepada suhu nyaman rata-rata di lokasi tertentu. Suhu ruang kelas yang nyaman untuk belajar di Indonesia berada antara $24^{\circ} \mathrm{C}-26^{\circ} \mathrm{C}$ (Hartawan, 2012). Pada aspek kebisingan, studi yang dilakukan Silva, Oliveira, dan Silva (2016) menemukan bahwa masalah kebisingan mengganggu siswa dalam mendengarkan penjelasan guru di dalam kelas selama proses belajar. Masalah tersebut dapat berimplikasi pada hasil belajar karena beberapa isi materi mungkin tidak ditangkap dengan baik oleh siswa, sehingga hasil belajar tidak maksimal. Hal tersebut diperkuat oleh hasil penelitian yang dilakukan Ali (2013) yang menemukan bahwa kebisingan merupakan masalah yang dapat menghambat keberhasilan siswa dalam belajar.

Selain kinerja bangunan, Djam'an (2000) menambahkan keindahan dan kerapian lingkungan sekolah juga merupakan faktor penting yang menentukan kualitas kinerja akademik siswa. Keindahan dan kerapian akan membuat siswa lebih nyaman berada pada lingkungan sekolah sehingga dapat membantu meningkatkan semangat dan motivasi belajar. 
Faktor-faktor di atas dilengkapi oleh Pedoman Pemenuhan Standar Nasional Pendidikan pada Sekolah Menengah Atas (SMA)/Madrasah Aliyah (MA), (2012) yang menyatakan bahwa luas lahan sekolah, kelayakan fasilitas, serta kemudahan dan keamanan akses ke setiap ruangan di sekolah merupakan hal fundamental yang harus ada di sekolah, khususnya SMA/MA.

\subsection{Lingkungan Non-Fisik Sekolah (Lingkungan Sosial)}

Salah satu tujuan sekolah adalah melatih siswa untuk bersosialisasi. Siswa diharapkan menjadi makhluk sosial yang seutuhnya dan mampu beradaptasi dengan baik di masyarakat. Oleh karena itu, ruang interaksi di sekolah sangat penting, demi mendukung berlangsungnya proses sosialisasi di sekolah (Hasbullah, 2006). Lingkungan non-fisik sekolah diasosiasikan dengan interaksi sosial di sekolah. Interaksi sosial yang terjadi di sekolah dapat dilihat pada interaksi antar-pengguna sekolah, yaitu siswa dan guru. Pada kasus ini, interaksi sosial ditinjau pada aspek yang terkait dengan unsur space sebagai wadah berinteraksi. Interaksi ini ditujukan pada interaksi antara siswa-dengansiswa serta interaksi antara siswa-dengan-guru.

Menurut Shannon dan Bylsma (2007) kegiatan seperti monitoring atau pengawasan terhadap perilaku siswa dan pencapaian akademik siswa merupakan salah satu aspek penting untuk meningkatkan performa sebuah sekolah. Oleh karena itu, sekolah harus bisa mengumpulkan data-data terkait dengan proses monitoring dengan leluasa. Shannon dan Bylsma (2007) kemudian memaparkan bahwa beberapa faktor yang berperan di dalam monitoring atau pengawasan adalah relasi (interaksi sosial) dan lingkungan yang aman dan terlindungi.

Interaksi sekolah dengan siswa tidak terlepas dari adanya aturan yang secara tidak langsung melekat pada siswa. Aturan ini biasanya bersifat kaku dan memiliki konsekuensi tertentu, namun pada hakikatnya berfungsi untuk mendukung tercapainya target kegiatan belajar mengajar. Prestasi siswa biasanya diapresiasi, demikian pula dengan pemberian sanksi untuk siswa yang melanggar aturan. (Ehiane, 2014) menemukan bahwa diterapkannya sanksi di sekolah merupakan sebuah faktor yang dapat meningkatkan kedisiplinan dan berimplikasi pada kualitas performa akademik siswa.

\subsection{Motivasi Belajar dan Kejenuhan Belajar}

Motivasi dan kejenuhan dalam belajar merupakan dua hal yang akan dihadapi siswa di dalam proses belajar di sekolah. Kedua hal ini timbul secara fluktuatif tergantung dengan stimulus yang diterima oleh siswa. Stimulus kemudian diterjemahkan oleh siswa dalam bentuk respons positif atau negatif. Respons positif akan menumbuhkan keinginan dan semangat untuk belajar, sementara respons yang negatif dalam kadar tertentu akan menjadikan seorang siswa menjadi jenuh dan enggan untuk melakukan tugas-tugas belajar.

Aritonang (2008) menjelaskan bahwa adanya motivasi belajar dapat dilihat melalui beberapa indikator, yaitu ketekunan dalam belajar, keuletan dalam menghadapi kesulitan, minat dan ketajaman perhatian dalam belajar, prestasi dalam belajar, serta kemandirian dalam belajar. Berdasarkan indikator di atas, dapat terlihat bahwa aspek motivasi dapat timbul dari dalam diri siswa, namun kondisinya berpotensi dipengaruhi keadaan lingkungan sekitar.

Selain menentukan motivasi belajar, lingkungan sekolah juga berpotensi menghadirkan kendala dalam belajar seperti kelelahan dan kejenuhan. Mercer-Lynn, Bar, dan Eastwood (2014) menemukan bahwa faktor yang berpotensi menimbulkan kejenuhan tersebut terkait dengan orang-orang di lingkungan sekolah dan situasi di sekolah. 


\subsection{Batasan dan Tujuan Penelitian}

Objek utama penelitian ini dibatasi pada pengguna sekolah menengah atas (SMA), khususnya siswa yang sedang menempuh pendidikan. Pada konteks ini, siswa berada pada usia remaja yaitu 13 sampai 20 tahun (Papalia, Olds, \& Feldman, 2008); (Ruswahyuningsih \& Afiatin, 2015), dengan kondisi emosi yang labil dan sedang dalam masa transformasi karakter (Hall, 2013). Rentang usia tersebut merupakan masa yang penting, karena seseorang akan menjalani proses menentukan karakteristik pribadi yang akan melekat pada diri mereka sampai lanjut usia.

Studi ini mencoba mengungkap hubungan kausal yang terjadi antara faktor eksternal-internal dan efektivitas belajar siswa dalam konteks lingkungan Sekolah Menengah Atas (SMA). Sekolah dipilih sebagai latar karena memiliki dimensi yang kompleks. Contohnya, keadaan sekolah, fasilitas atau perlengkapan sekolah, kurikulum, maupun kualitas guru. Dimensi-dimensi tersebut dapat saling berpengaruh pada kualitas kinerja akademik siswa.

\subsection{Metode Penelitian}

Penelitian ini menggunakan metode kualitatif pada tahap pertama dan metode kuantitatif pada tahap kedua seperti yang dikemukakan oleh Cresswell (2008). Pada tahap pertama dilakukan penelitian kualitatif yang bersifat eksploratif (Groat \& Wang, 2002) untuk mendapatkan faktor-faktor pada lingkungan sekolah yang dapat meningkatkan semangat belajar. Faktor-faktor tersebut kemudian dilengkapi melalui studi literatur dan diproses kembali menggunakan pendekatan kuantitatif pada tahap kedua (Groat \& Wang, 2002). Secara diagram, metode penelitian ini dapat dilihat pada gambar 1 .

Pada tahap pertama, kuesioner dikirimkan secara non-random (snowball sampling) selama sepuluh hari (27 Agustus 2017 hingga 5 September 2017) kepada teman sebaya dan kolega untuk kemudian diteruskan kembali kepada relasi yang mereka punya. Kuesioner yang diajukan pada tahap ini bersifat terbuka (open-ended) sehingga memungkinkan responden menuliskan jawaban sespesifik mungkin. Studi tahap pertama mengikutsertakan 140 responden, dengan perincian 54\% perempuan dan 46\% laki-laki. Responden berasal dari berbagai jenjang pendidikan, mulai dari jenjang SMA (38,8\%), D3 $(3,4 \%)$, S1 (44\%), S2 (12,1\%), hingga jenjang S3 (1,7\%). Selain itu, mereka berasal dari latar belakang pekerjaan yang sangat beragam, mulai dari pelajar, dosen, praktisi di bidang arsitektur, hingga wiraswasta di berbagai kota. Tujuannya adalah untuk memperoleh skala pengetahuan yang lebih luas dan mewakili berbagai perspektif (berdasarkan pengalaman responden), sehingga didapatkan faktor lingkungan belajar yang dapat meningkatkan semangat belajar secara ideal. Namun, dari 140 data tersebut, hanya terdapat 110 data yang valid untuk dianalisis.

Pada tahap kedua, penelitian ini difokuskan ke siswa SMA/sederajat dengan ketentuan telah berada pada lingkungan sekolah minimum selama satu tahun, atau alumni SMA/sederajat yang telah lulus maksimum selama satu tahun. Ketentuan tersebut dibuat agar responden memiliki nalar yang cukup untuk mengenal dan menilai lingkungan tempat mereka belajar. Kuesioner pada tahap kedua bersifat tertutup (close-ended) dan berisi form penilaian kondisi lingkungan sekolah mereka masing-masing berdasarkan indikator lingkungan belajar dan respons pengguna yang telah didapatkan dari penelitian tahap pertama. Pada tahap ini, diperoleh data dari 110 responden dengan perincian $64 \%$ perempuan dan 36\% laki-laki dari berbagai kota. Dari rentang usia 15 sampai dengan 20 tahun, responden didominasi usia 18 tahun (60,3\%) dan 17 tahun (26,8\%). Kuesioner tahap kedua ini juga disebarkan selama sepuluh hari (19 Oktober 2017 hingga 29 Oktober 2017). 


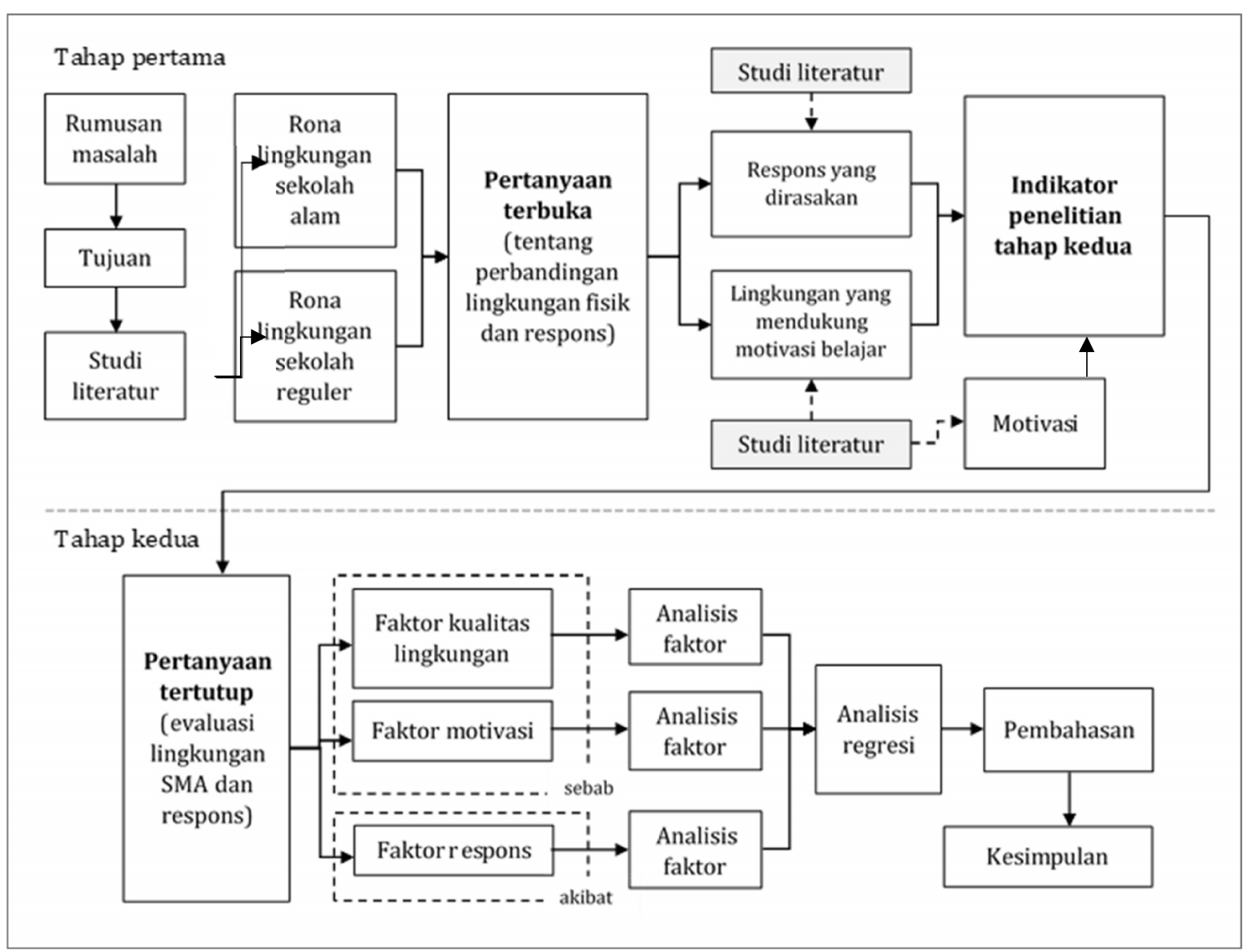

Gambar 1. Diagram Penelitian

Pada pengumpulan data tahap pertama, responden diminta untuk menuliskan pendapat mereka mengenai dua jenis lingkungan sekolah yang dapat meningkatkan motivasi dan semangat belajar yang disajikan dalam bentuk foto. Foto tersebut memperlihatkan perbandingan antara rona lingkungan sekolah alam dan sekolah reguler. Pendapat-pendapat tersebut kemudian diolah melalui analisis isi untuk mendapatkan variabel-variabel lingkungan fisik yang berpotensi meningkatkan motivasi belajar siswa serta variabel-variabel respons yang cenderung dirasakan pada situasi lingkungan tertentu.

Berdasarkan hasil analisis tahap pertama, didapatkan hasil bahwa: kesejukan/kesegaran udara; kebersihan udara; keasrian; kenyamanan; ketenangan; sarana yang permanen; kelengkapan fasilitas; kerapian tata ruang; aksesibilitas; serta keamanan, merupakan variabel-variabel lingkungan fisik yang mendukung motivasi belajar. Sedangkan, pikiran yang fresh; perasaan senang; kejenuhan; perasaan santai; keleluasaan; keaktifan; konsentrasi; mood; kreativitas; produktivitas; situasi kondusif; tingkat fokus; apresiasi sekolah; serta kedisiplinan, merupakan variabel respons yang cenderung dirasakan pengguna.

Studi literatur dilakukan untuk melengkapi variabel yang akan digunakan untuk kuesioner tahap kedua. Kemudian didapatkan variabel-variabel tambahan pada faktor fisik, yaitu luas lahan sekolah dan kelayakan fasilitas di sekolah seperti ruang UKS, tempat bermain/taman/lapangan olahraga, dan toilet (Pedoman Pemenuhan Standar Nasional Pendidikan pada Sekolah Menengah Atas (SMA)/Madrasah Aliyah (MA), 2012); serta kinerja ruang-ruang penting di sekolah (kelas, perpustakaan, laboratorium/bengkel) meliputi kenyamanan visual dan termal yang ditinjau dari kerapian, pencahayaan, dan sirkulasi udara (Djam'an, 2000). Pada faktor non-fisik (sosial), variabel yang dirujuk 
adalah variabel yang berhubungan dengan ruang yang digunakan untuk bersosialisasi, baik siswa dengan siswa maupun siswa dengan guru (Hasbullah, 2006), monitoring sekolah terhadap siswanya (Shannon \& Bylsma, 2007), serta kedisiplinan di sekolah (Ehiane, 2014). Pada faktor motivasi, digunakan variabel-variabel yang sesuai dengan teori yang dikemukakan oleh Aritonang (2008).

Pada pengumpulan data tahap kedua, responden (siswa SMA/MA/setara) diminta menilai kualitas lingkungan sekolahnya dan menilai apa yang mereka rasakan. Setiap pertanyaan pada kuesioner memiliki skala 1 sampai 5 (tabel 1 ).

Tabel 1. Contoh Pertanyaan Kuesioner Tahap 2

\begin{tabular}{|c|c|}
\hline Kategori & Contoh Pertanyaan \\
\hline \multirow{2}{*}{ Lingkungan Fisik } & Udara di sekolah saya sejuk/segar \\
\hline & $\begin{array}{llllll}\text { Sangat tidak setuju } & 1 & 2 & 3 & 4 & 5\end{array}$ \\
\hline \multirow[t]{2}{*}{ Lingkungan Sosial } & $\begin{array}{l}\text { Sekolah saya memiliki tempat ngobrol/diskusi yang } \\
\text { asyik }\end{array}$ \\
\hline & Sangat tidak setuju \\
\hline \multirow{2}{*}{ Respons } & Saya merasa senang belajar di sekolah saya \\
\hline & $\begin{array}{llllll}\text { Sangat tidak setuju } & 1 & 2 & 3 & 4 & 5\end{array}$ \\
\hline \multirow{2}{*}{ Motivasi } & Saya adalah siswa yang rajin hadir di sekolah \\
\hline & Sangat tidak setuju \\
\hline
\end{tabular}

Data numerik yang dihasilkan dari pertanyaan tersebut kemudian dianalisis secara kuantitatif menggunakan analisis komponen prinsip, analisis faktor, dan analisis regresi. Analisis komponen prinsip digunakan untuk menyederhanakan keseluruhan data tanpa mengurangi karakteristik data tersebut secara signifikan (Johnson \& Wichern, 1998). Analisis faktor digunakan untuk menentukan variabel laten (dimensi) yang memiliki kemampuan menjelaskan keseluruhan variabel pada masing-masing kategori. Masingmasing variabel laten dianalisis lebih lanjut menggunakan analisis regresi untuk menentukan besar hubungan antar variabel laten tersebut.

\section{Hasil dan Diskusi}

Analisis komponen prinsip dilakukan dengan menggunakan Kaiser's stopping rule. Aturan tersebut diaplikasikan dengan cara mengekstraksi jumlah komponen prinsip yang memiliki eigenvalue lebih dari 1. Hal ini berarti setiap komponen prinsip tersebut memiliki variabilitas melebihi variabel terukur dan dapat merepresentasikan/mewakili variabel terukur.

Selanjutnya, dilakukan analisis faktor untuk menentukan variabel laten (dimensi) yang nantinya akan menjelaskan variabel-variabel terukur di dalamnya. Pada tahap ini, komponen prinsip diolah menggunakan varimax rotation. Tujuannya adalah agar antar komponen prinsip tidak saling terkorelasi, dengan cara menjadikan factor loading dari variabel terukur tertentu besar pada dimensi tertentu dan mendekati nol pada dimensi yang lain. Proses analisis ini dilakukan pada tiga kategori, yaitu kategori kualitas lingkungan SMA, kategori motivasi siswa SMA, dan kategori respons siswa SMA.

Pada kategori kualitas lingkungan SMA, peneliti mengambil delapan komponen prinsip dengan kemampuan menjelaskan fenomena sebanyak 69.7\%. Setelah dilakukan analisis faktor, didapatkan delapan dimensi kualitas lingkungan sekolah, yaitu "interaksi sosial dan pengawasan", "keteraturan ruang kelas", "kualitas udara", "kualitas 
perpustakaan", "kualitas laboratorium/bengkel”, "kualitas fasilitas pendukung”, "kekuatan dan kelengkapan", serta "potensi gangguan" (tabel 2).

\section{Tabel 2. Variabel Laten (Dimensi) dari Hasil Analisis Faktor Kualitas Lingkungan SMA}

\begin{tabular}{|c|c|c|c|c|c|c|c|c|}
\hline & $\begin{array}{c}\text { Interaksi } \\
\text { Sosial dan } \\
\text { Pengawasan }\end{array}$ & $\begin{array}{l}\text { Keteraturan } \\
\text { Ruang } \\
\text { Kelas }\end{array}$ & $\begin{array}{l}\text { Kualitas } \\
\text { Udara }\end{array}$ & $\begin{array}{c}\text { Kualitas } \\
\text { Perpustakaan }\end{array}$ & $\begin{array}{c}\text { Kualitas } \\
\text { Lab/Bengkel }\end{array}$ & $\begin{array}{l}\text { Kualitas } \\
\text { Fasilitas } \\
\text { Pendukung }\end{array}$ & $\begin{array}{l}\text { Kekuatan } \\
\text { dan } \\
\text { Kelengkapan }\end{array}$ & $\begin{array}{l}\text { Potensi } \\
\text { Gangguan }\end{array}$ \\
\hline $\begin{array}{l}\text { Ruang Komunal Guru- } \\
\text { Siswa }\end{array}$ & 0.73 & 0.17 & 0.29 & 0.19 & 0.03 & 0.12 & -0.09 & 0.11 \\
\hline $\begin{array}{l}\text { Ruang Komunal Siswa- } \\
\text { Siswa }\end{array}$ & 0.73 & 0.13 & 0.27 & 0.15 & 0.08 & 0.08 & -0.14 & 0.13 \\
\hline Kedisiplinan & 0.69 & 0.01 & 0.12 & 0.17 & 0.26 & 0.11 & 0.36 & -0.08 \\
\hline Monitoring & 0.69 & 0.12 & 0.01 & 0.05 & 0.30 & 0.14 & 0.24 & -0.18 \\
\hline Keamanan Akses & 0.56 & 0.45 & 0.02 & 0.24 & 0.09 & 0.15 & 0.06 & -0.30 \\
\hline Kerapian Kelas & 0.15 & 0.64 & 0.29 & 0.20 & 0.34 & 0.18 & -0.02 & -0.14 \\
\hline Keamanan & 0.13 & 0.59 & 0.08 & 0.06 & 0.06 & 0.19 & 0.19 & -0.26 \\
\hline Tata Ruang & 0.16 & 0.56 & 0.25 & 0.34 & 0.29 & 0.02 & 0.38 & -0.06 \\
\hline Kemudahan Akses & 0.44 & 0.53 & 0.00 & 0.29 & -0.05 & 0.16 & 0.14 & -0.17 \\
\hline Pencahayaan Kelas & 0.02 & 0.52 & 0.25 & 0.04 & 0.51 & 0.26 & -0.14 & 0.01 \\
\hline Sirkulasi Udara Kelas & 0.06 & 0.48 & 0.43 & -0.06 & 0.42 & 0.36 & -0.08 & -0.02 \\
\hline Apresiasi Sekolah & 0.44 & 0.46 & 0.11 & 0.10 & 0.22 & 0.18 & 0.09 & 0.23 \\
\hline Kenyamanan Toilet & 0.18 & 0.47 & 0.17 & 0.30 & 0.05 & 0.29 & 0.05 & 0.03 \\
\hline Kesejukan Udara & 0.13 & 0.08 & 0.86 & 0.15 & 0.13 & 0.11 & 0.08 & -0.03 \\
\hline Kebersihan Udara & 0.16 & 0.24 & 0.72 & 0.19 & 0.23 & 0.11 & 0.17 & -0.17 \\
\hline Keasrian & 0.19 & 0.05 & 0.68 & 0.15 & 0.10 & 0.31 & 0.11 & -0.04 \\
\hline Kenyamanan & 0.22 & 0.42 & 0.65 & 0.11 & 0.12 & 0.18 & 0.22 & -0.11 \\
\hline $\begin{array}{l}\text { Sirkulasi Udara } \\
\text { Perpustakaan }\end{array}$ & 0.18 & 0.17 & 0.12 & 0.78 & 0.27 & 0.14 & 0.09 & -0.01 \\
\hline Pencahayaan Perpustakaan & 0.11 & 0.21 & 0.22 & 0.75 & 0.20 & 0.06 & 0.12 & -0.02 \\
\hline Kerapian Perpustakaan & 0.29 & 0.10 & 0.13 & 0.75 & 0.18 & 0.24 & 0.11 & -0.01 \\
\hline $\begin{array}{l}\text { Pencahayaan } \\
\text { Laboratorium/Bengkel }\end{array}$ & 0.17 & 0.08 & 0.09 & 0.27 & 0.79 & 0.17 & 0.04 & -0.10 \\
\hline $\begin{array}{l}\text { Sirkulasi Udara } \\
\text { Laboratorium/Bengkel }\end{array}$ & 0.21 & 0.15 & 0.20 & 0.22 & 0.78 & 0.15 & 0.15 & 0.02 \\
\hline $\begin{array}{l}\text { Kerapian Laboratorium/ } \\
\text { Bengkel }\end{array}$ & 0.25 & 0.24 & 0.19 & 0.41 & 0.62 & 0.12 & 0.07 & -0.06 \\
\hline Luas Lahan & -0.02 & 0.08 & 0.15 & 0.00 & 0.34 & 0.71 & 0.09 & 0.01 \\
\hline $\begin{array}{l}\text { Kenyamanan Tempat } \\
\text { Bermain/Taman/Lapangan } \\
\text { Olahraga }\end{array}$ & 0.15 & 0.26 & 0.21 & 0.21 & 0.14 & 0.67 & 0.15 & -0.13 \\
\hline Kenyamanan UKS & 0.24 & 0.21 & 0.16 & 0.31 & 0.02 & 0.64 & 0.10 & -0.06 \\
\hline Ruang Ngobrol/Diskusi & 0.33 & 0.27 & 0.16 & 0.10 & 0.08 & 0.58 & 0.08 & -0.02 \\
\hline Permanen & 0.06 & 0.10 & 0.23 & 0.14 & 0.02 & 0.21 & 0.74 & 0.00 \\
\hline Kelengkapan Fasilitas & 0.11 & 0.48 & 0.15 & 0.30 & 0.15 & 0.14 & 0.54 & 0.02 \\
\hline Kebisingan & 0.06 & -0.07 & -0.10 & -0.18 & 0.00 & -0.16 & 0.28 & 0.77 \\
\hline Pencemaran Lingkungan & -0.06 & -0.15 & -0.11 & 0.14 & -0.10 & 0.05 & -0.25 & 0.76 \\
\hline
\end{tabular}

Pada tabel 2, dapat dilihat bahwa dimensi kualitas lingkungan yang paling dominan adalah "interaksi sosial dan pengawasan". Secara umum, dimensi ini melingkupi aspekaspek sosial yang diterapkan pada sekolah, seperti adanya ruang-ruang interaksi, sanksi sekolah, dan monitoring. Hal ini mendukung teori dalam konteks pendidikan seperti pendapat Hasbullah (2006) tentang sekolah sebagai sarana interaksi sosial, Shannon dan Bylsma (2007) tentang monitoring sebagai faktor pendorong performa sekolah, serta Stanley (2014) tentang sanksi sekolah demi efektivitas kegiatan belajar mengajar. Selain itu, hasil analisis ini juga sesuai dengan temuan penelitian yang dikemukakan oleh Riyani (2012) yang menyatakan bahwa dimensi interaksi sosial ini juga merupakan faktor yang mempengaruhi prestasi belajar seseorang yang berusia remaja. Oleh karena itu, rancangan 
yang baik tentang ruang-ruang interaksi di sekolah menjadi sangat penting agar proses interaksi sosial di sekolah dapat terjadi dan meningkatkan kualitas lingkungan sekolah.

Selain aspek sosial, faktor selanjutnya yang menentukan kualitas sekolah adalah lingkungan fisiknya. Pada konteks ini, kinerja ruang sangat berperan dalam menentukan kinerja siswa di sekolah. Tingkat kenyamanan (baik visual maupun termal), kerapian dan keindahan, serta keamanan, merupakan aspek-aspek yang perlu diberikan perhatian lebih di dalam sebuah rancangan sekolah. Penelitian-penelitian lain yang dilakukan dalam lingkup bangunan pendidikan juga menyatakan hal yang sama. Diperlukan adanya elemenelemen alami seperti taman yang tertata rapi dan dirancang secara khusus sebagai area istirahat dan bersantai sejenak dari kepenatan kegiatan belajar mengajar. Selain itu, semakin banyak area hijau yang terdapat pada sekolah, semakin baik pula kualitas udara dan kualitas kenyamanan di sekolah tersebut (Setyabudi, Nuraini, Alfian, \& Nailufar, 2017).

Selanjutnya, sekolah juga harus memiliki kualitas sarana dan prasarana yang baik untuk menunjang efektivitas belajar mengajar. Gedung, tanah, hingga perlengkapan administrasi merupakan hal yang mendasar di dalam lingkup bangunan pendidikan. Dimensi ini mendukung terciptanya iklim sosio-emosional di sekolah dan membantu pendidik dalam meningkatkan efektivitas proses belajar (Megasari, 2014). Rancangan sekolah juga harus mampu mereduksi gangguan yang datang dari luar sekolah seperti kebisingan dan pencemaran udara, karena berpotensi mengganggu proses belajar mengajar di sekolah. Hal ini sesuai dengan hasil penelitian yang dikemukakan Ali (2013), bahwa proses belajar mengajar akan terganggu dan berpotensi menurunkan prestasi belajar apabila gangguan eksternal seperti kebisingan terdapat di sekitar sekolah.

Berdasarkan analisis komponen prinsip yang dilakukan pada kategori respons siswa, didapatkan dua komponen prinsip dengan kemampuan menjelaskan fenomena sebesar 59.6\%. Dua komponen prinsip tersebut selanjutnya diolah menggunakan analisis faktor dan ditemukan bahwa "efektivitas belajar" dan "gangguan belajar" adalah dua respons utama yang akan muncul pada siswa berdasarkan tingkat kualitas lingkungan sekolah (tabel 3).

Tabel 3. Variabel Laten (Dimensi) dari Hasil Analisis Faktor Respons Siswa SMA

\begin{tabular}{lrr}
\hline & $\begin{array}{c}\text { Efektivitas } \\
\text { Belajar }\end{array}$ & \multicolumn{2}{c}{$\begin{array}{c}\text { Gangguan } \\
\text { Belajar }\end{array}$} \\
\hline Fokus & $\mathbf{0 . 8 2}$ & -0.14 \\
\hline Kondusif & $\mathbf{0 . 7 6}$ & -0.24 \\
\hline Disiplin & $\mathbf{0 . 7 5}$ & -0.15 \\
\hline Produktif & $\mathbf{0 . 7 4}$ & 0.01 \\
\hline Pikiran Fresh & $\mathbf{0 . 7 0}$ & -0.37 \\
\hline Kesenangan & $\mathbf{0 . 6 9}$ & -0.41 \\
\hline Kreatif & $\mathbf{0 . 6 8}$ & 0.01 \\
\hline Mood & $\mathbf{0 . 6 8}$ & -0.38 \\
\hline Konsentrasi & $\mathbf{0 . 6 6}$ & -0.37 \\
\hline Keaktifan & $\mathbf{0 . 6 4}$ & -0.33 \\
\hline Keleluasaan & $\mathbf{0 . 5 7}$ & -0.46 \\
\hline Ketegangan Pikiran & 0.02 & $\mathbf{0 . 8 0}$ \\
\hline Kejenuhan & -0.27 & $\mathbf{0 . 7 8}$ \\
\hline
\end{tabular}

Seperti yang terlihat pada variabel laten di tabel 3, kondisi lingkungan sekolah dapat memberikan efek yang positif maupun negatif pada siswa. Kondisi lingkungan sekolah yang baik cenderung dapat meningkatkan efektivitas belajar, sementara kondisi lingkungan sekolah yang kurang baik menimbulkan gangguan belajar.

Melalui proses analisis yang sama, didapatkan dua komponen prinsip pada aspek motivasi yang mampu menjelaskan variabel keseluruhan sebesar $52 \%$. Terdapat dua jenis 
motivasi belajar pada siswa SMA, yaitu "ketahanan dan peningkatan kemampuan" dan "kemandirian dan keberhasilan" (Tabel 4).

Tabel 4. Variabel Laten (Dimensi) dari Hasil Analisis Faktor Motivasi Siswa SMA

\begin{tabular}{lrr}
\hline & $\begin{array}{c}\text { Ketahanan dan } \\
\text { Peningkatan } \\
\text { Kemampuan }\end{array}$ & $\begin{array}{c}\text { Kemandirian dan } \\
\text { Keberhasilan }\end{array}$ \\
\hline Semangat Belajar & $\mathbf{0 . 7 6}$ & 0.31 \\
\hline Memanfaatkan Waktu & $\mathbf{0 . 7 4}$ & 0.12 \\
\hline Tidak Mengeluh & $\mathbf{0 . 7 3}$ & -0.14 \\
\hline Memperhatikan guru & $\mathbf{0 . 7 3}$ & 0.33 \\
\hline Bertanya & $\mathbf{0 . 6 0}$ & 0.19 \\
\hline Kehadiran Sekolah & $\mathbf{0 . 4 8}$ & 0.45 \\
\hline Ranking & $\mathbf{0 . 4 9}$ & 0.32 \\
\hline Belajar di Rumah & 0.20 & $\mathbf{0 . 8 2}$ \\
\hline Mengerjakan PR & 0.14 & $\mathbf{0 . 7 9}$ \\
\hline Hasil Belajar & 0.03 & $\mathbf{0 . 6 1}$ \\
\hline Kehadiran Kelas & 0.36 & $\mathbf{0 . 5 0}$ \\
\hline
\end{tabular}

"Ketahanan dan peningkatan kemampuan" adalah motivasi yang diperlihatkan siswa di sekolah seperti semangat belajar, tingkat perhatian kepada materi pembelajaran, serta keaktifan di kelas. Motivasi seperti ini dapat disebut juga interaksi dengan materi pembelajaran (Riyani, 2012). Interaksi dengan materi pembelajaran yang semakin intensif akan menjadikan proses belajar semakin efektif. Hal ini berpengaruh juga dalam meningkatkan prestasi belajarnya. Sedangkan "kemandirian dan keberhasilan" adalah motivasi belajar yang diperlihatkan siswa di tempat di luar sekolah. Indikator motivasi seperti ini dapat dilihat pada kegiatan belajar di rumah atau mengerjakan PR.

Hubungan antara dimensi lingkungan, dimensi motivasi, dan dimensi respons belajar kemudian dianalisis menggunakan analisis regresi. Dimensi lingkungan merupakan faktor eksternal dan dimensi motivasi merupakan faktor internal yang menjadi faktor independen yang mempengaruhi dimensi respons belajar yang menjadi faktor dependen. Berdasarkan analisis regresi (Tabel 5), peningkatan efektivitas belajar ditentukan oleh interaksi sosial dan pengawasan, keteraturan, kenyamanan, dan motivasi siswa. Sedangkan kualitas udara yang buruk, kebisingan, dan pencemaran lingkungan di sekolah dapat mengganggu kinerja akademik siswa.

Tabel 5. Tabel Regresi Antar Variabel Laten

\begin{tabular}{|c|c|c|c|c|}
\hline & \multicolumn{2}{|c|}{ Efektivitas Belajar } & \multicolumn{2}{|c|}{ Gangguan Belajar } \\
\hline & Bobot regresi & $\begin{array}{c}\text { Sig. } \\
\text { Value }\end{array}$ & Bobot regresi & $\begin{array}{c}\text { Sig. } \\
\text { Value }\end{array}$ \\
\hline \multicolumn{5}{|l|}{ Dimensi Kualitas Lingkungan } \\
\hline Interaksi Sosial dan Pengawasan & $0.32 * * *$ & $<.0001$ & -0.11 & 0.1067 \\
\hline Keteraturan Ruang Kelas & $0.35^{* * *}$ & $<.0001$ & -0.07 & 0.2961 \\
\hline Kualitas Udara & $0.28 * * *$ & $<.0001$ & $-0.22 * *$ & 0.0013 \\
\hline Kualitas Perpustakaan & $0.18 * *$ & 0.0004 & -0.03 & 0.6121 \\
\hline Kualitas Lab/Bengkel & $0.18^{* *}$ & 0.0007 & -0.03 & 0.6911 \\
\hline Kualitas Fasilitas Pendukung & $0.21 * * *$ & $<.0001$ & -0.09 & 0.1905 \\
\hline Kekuatan dan Kelengkapan & $0.13^{*}$ & 0.016 & -0.08 & 0.2611 \\
\hline Potensi Gangguan & 0.06 & 0.2725 & $0.36^{* * *}$ & $<.0001$ \\
\hline \multicolumn{5}{|l|}{ Dimensi Motivasi } \\
\hline Ketahanan dan Peningkatan Kemampuan & $0.21 * * *$ & 0.0001 & -0.08 & 0.2704 \\
\hline \multirow[t]{2}{*}{ Kemandirian dan Keberhasilan } & $0.11^{*}$ & 0.0443 & -0.11 & 0.1106 \\
\hline & \multicolumn{2}{|c|}{$\mathrm{P}<.0001 \mathrm{RSq}=0.58$} & \multicolumn{2}{|c|}{$\mathrm{P}<.0001 \mathrm{RSq}=0.25$} \\
\hline
\end{tabular}


Berdasarkan analisis yang telah dilakukan, dapat dilihat bahwa faktor eksternal lebih besar mempengaruhi efektivitas belajar daripada faktor internal. Faktor-faktor eksternal seperti "keteraturan ruang kelas" (0.35), "interaksi sosial dan pengawasan" (0.32), "kualitas udara" (0.28), serta "kualitas fasilitas pendukung" (0.21) dan faktor internal "ketahanan dan peningkatan kemampuan" (0.21) secara signifikan mempengaruhi efektivitas belajar siswa.

Interpretasi lain berdasarkan seluruh analisis yang telah dilakukan terkait dengan efektivitas belajar adalah kualitas fisik, spasial, dan sosial yang dirasakan dan digunakan langsung oleh siswa sehari-hari dengan intensitas tinggi cenderung lebih mempengaruhi efektivitas belajar dibandingkan fasilitas yang digunakan dengan intensitas rendah. Ruang kelas, lapangan olah raga, area bermain dan istirahat (taman), hingga area tempat duduk untuk me-ngobrol atau diskusi, merupakan ruang-ruang yang harus diberikan perhatian lebih dalam perancangan karena secara rutin digunakan oleh siswa dan dapat mempengaruhi efektivitas belajar.

Hubungan kausal yang terjadi pada konteks penelitian ini kemudian direpresentasikan ke dalam sebuah model diagram yang berfungsi untuk memudahkan penjelasan hasil penelitian dan menggambarkan fenomena yang terjadi di lingkungan SMA. Gambar 2 menjelaskan model diagram hubungan kausal antara dimensi "lingkungan SMA", "motivasi siswa", dan "respons siswa".

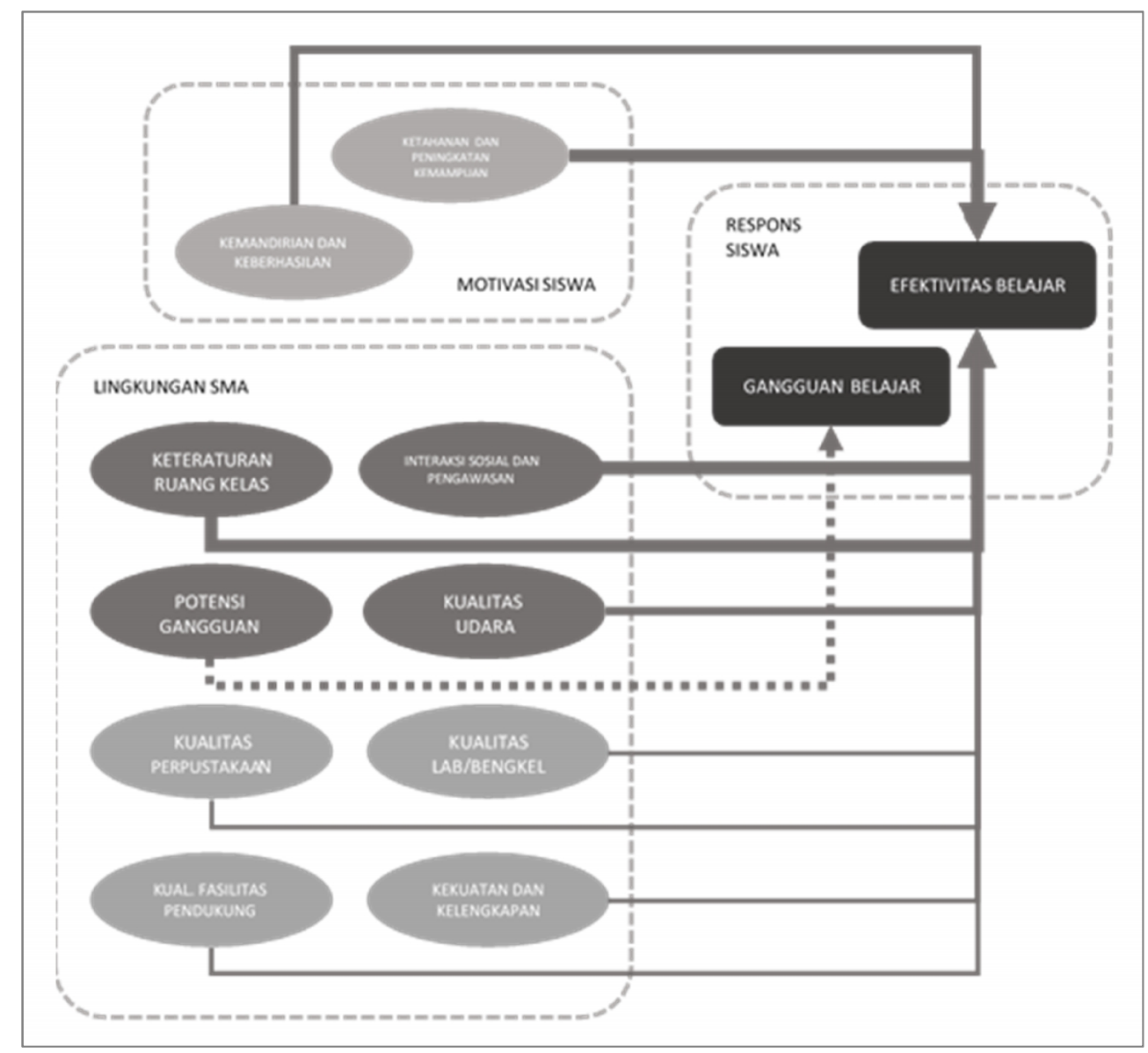

Gambar 2. Model Hubungan Kausal Lingkungan SMA, Motivasi Siswa, dan Respons Siswa

Model diagram di atas dibangun berdasarkan besar koefisien regresi yang berkontribusi pada aspek respons siswa. Ketebalan garis menunjukkan tingkat besaran koefisien. Semakin tebal garis yang terdapat pada diagram, semakin besar pula nilai 
koefisien regresi, begitu pula sebaliknya. Dimensi yang paling berpengaruh terhadap peningkatan kinerja akademik siswa adalah keteraturan ruang kelas dan interaksi sosial/pengawasan. Sedangkan gangguan seperti kualitas udara yang buruk, kebisingan, dan pencemaran lingkungan akan mengganggu kinerja akademik siswa.

\section{Kesimpulan}

Studi ini menemukan bahwa faktor eksternal lebih cenderung mempengaruhi efektivitas belajar siswa di sekolah dibandingkan faktor internal. Faktor eksternal yang mempengaruhi efektivitas belajar siswa adalah "keteraturan ruang kelas", "interaksi sosial dan pengawasan" baik pihak sekolah terhadap siswanya maupun antara siswa dengan siswa, "kualitas udara" ruang-ruang di sekolah, "kualitas perpustakaan", "kualitas laboratorium/bengkel”, "kualitas fasilitas pendukung”, "kekuatan dan kelengkapan”, serta "potensi gangguan" yang terdapat di sekitar sekolah. Kedelapan variabel laten ini dapat dijadikan parameter rancangan sebuah SMA untuk meningkatkan kualitas lingkungan, baik secara fisik maupun non-fisik. Namun, terdapat faktor lain yang juga berperan pada kinerja akademik siswa yaitu motivasi. Motivasi siswa dapat dilihat pada sikap siswa dalam hal ketahanan dan peningkatan kemampuan, serta kemandirian dan keberhasilan.

\section{Rekomendasi}

Hasil kesimpulan di atas memiliki tingkat generalisasi yang terbatas karena menggunakan teknik non-random sampling (sampel hanya dipilih secara umum berdasarkan kriteria tertentu). Sehingga, faktor-faktor tersebut hanya berpengaruh pada kriteria sampel yang digunakan. Diperlukan adanya replikasi penelitian dengan teknik random sampling untuk meningkatkan tingkat generalisasi dan reliabilitas hasil penelitian.

Penelitian ini hanya mengungkap kualitas sekolah dari perspektif responden. Perspektif tersebut dapat berpotensi menurunkan objektivitas karena masing-masing responden memiliki persepsi masing-masing terhadap kualitas lingkungan sekolah. Untuk mengetahui kualitas lingkungan sekolah dengan lebih baik dan objektif, diperlukan studi lebih lanjut secara empiris tentang variabel-variabel yang menentukan kualitas sekolah, sehingga peneliti dapat mengetahui berbagai jenis karakteristik lingkungan sekolah secara langsung dan merasakan kualitas lingkungan di sekolah baik fisik maupun non-fisik.

\section{Daftar Pustaka}

Ali, S. A. (2013). Study effects of school noise on learning achievement and annoyance in Assiut city, Egypt. Applied Accoustics, 74(2013), 602-606. doi:10.1016/j.apacoust.2012.10.011

Aritonang, K. T. (2008). Minat dan Motivasi dalam Meningkatkan Hasil Belajar Siswa. Jurnal Pendidikan Penabur, 10(7), 11-21.

Berger, K. S., \& Thompson, R. A. (1995). The Developing Person Through Childhood and Adolescence. New York: Worth Publishers.

Cresswell, J. W. (2008). Educational Research: Planning, Conducting, and Evaluating Quantitative and Qualitative Research. Upper Saddle River, NJ: Pearson/Merrill Prentice Hall.

Dalyono, M. (2009). Psikologi Pendidikan. Jakarta: Rineka Cipta.

Darwin, M. (2010). Dinamika Kependudukan \& Penguatan Governance. Yogyakarta: Media Wacana.

Davison, K. K., \& Lawson, C. T. (2006). Do attributes in the physical environment influence childrens physical activity? A review of the literature. International Journal of Behavioral Nutrition and Physical Activity, 3(19), x-x. doi:10.1186/1479-5868-3-19 
Djam'an, S. (2000). Dimensi Indikator Sekolah Efektif. Seminar Nasional HMJ Administrasi Pendidikan FIP (hal. $\mathrm{x}-\mathrm{x}$ ). Bandung: UPI.

Ehiane, O. S. (2014). Discipline and Academic Performance (A Study of Selected Secondary Schools in Lagos, Nigeria). International Journal of Academic Research in Progeressive Education and Development, 3(1), 181-194. doi:10.6007/IJARPED/v3-i1/758

Ellis, R. S. (1965). Educational Prychology: A Problem Approach. New Delhi: Affiliated East-West Press.

Greenman, J. (1988). Caring Spaces, Learning Places: Children's Environments that Work. Redmond, WA: Exchange Press.

Groat, L. N., \& Wang, D. (2002). Architectural Research Methods. Hoboken, NJ: John Wiley $\&$ Sons.

Hall, G. S. (2013). Adolescence - Its Psychology and Its Relations to Physiology, Anthropology, Sociology, Sex, Crime, and Religion (1931). Worcestershire: Read Books Limited.

Hartawan, A. (2012). Studi Pengaruh Suhu Terhadap Kecepatan Respon Mahasiswa Di Ruang Kelas dengan Metode Design of Experiment. Depok: Universitas Indonesia (Undergraduate Thesis, Unpublished).

Hasbullah. (2006). Dasar-dasar Ilmu Pendidikan. Jakarta: Raja Grafindo Persada.

Hodson, C. B., \& Sander, H. A. (2017). Green urban landscapes and school academic performance. Landscape and Urban Planning, 160(2017), 16-27. doi:10.1016/j.landurbplan.2016.11.011

Johnson, R. A., \& Wichern, D. W. (1998). Applied Multivariate Statistical Analysis. New Jersey: Prentice-Hall International Inc.

Kementerian Pendidikan dan Kebudayaan. (2012). Pedoman Pemenuhan Standar Nasional Pendidikan pada Sekolah Menengah Atas (SMA)/Madrasah Aliyah (MA). Jakarta: Kementerian Pendidikan dan Kebudayaan.

Koontz, Harold, O'Donell, C., \& Weihrich, H. (2001). Manajemen. Jakarta: Erlangga.

Kweon, B.-S., Ellis, C. D., Lee, J., \& Jacobs, K. (2017). The link between school environments and student academic performance. Urban Forestry \& Urban Greening, 23(2017), 35-43. doi:10.1016/j.ufug.2017.02.002

Megasari, R. (2014). Peningkatan Pengelolaan Sarana dan Prasarana Pendidikan untuk Meningkatkan Kualitas Pembelajaran di SMPN 5 Bukittinggi. Jurnal Administrasi Pendidikan, 2(1), 647-831.

Mercer-Lynn, K. B., Bar, R. J., \& Eastwood, J. D. (2014). Causes of boredom: The person, the situastion, or both? Personality and Individual Differences, 56(2014), 122-126. doi:10.1016/j.paid.2013.08.034

Michael, A., \& Heracleous, C. (2017). Assessment of natural lighting performance and visual comfort of educational architecture in Southern Europe: The case of typical educational school premises in Cyprus. Energy and Buildings, 140(2017), 443-457. doi:10.1016/j.enbuild.2016.12.087

Papalia, D., Olds, S., \& Feldman, R. (2008). Human Development (11th ed.). New York: McGraw-Hill Education.

Pujadi, A. (2007). Faktor-faktor yang Mempengaruhi Motivasi Belajar Mahasiswa: Studi Kasus Pada Fakultas Ekonomi Universitas Bunda Mulia. Business \& Management Journal Bunda Mulia, 3(2), 40-51.

Ramli, N. H., Ahmad, S., Taib, M. Z., \& Masri, M. (2014). Principals' Perception on Classroom Physical Environment. Procedia - Social and Behavioral Sciences, 153(2014), 266-273. doi:10.1016/j.sbspro.2014.10.060 
Republik Indonesia. (2003). Undang-undang No. 20 Tahun 2003 tentang Sistem Pendidikan Nasional. Jakarta: Sekretariat Negara. Diambil kembali dari Dirjen Kelembagaan Iptek \& Dikti Kemenristekdikti.

Riyani, Y. (2012). Faktor-faktor yang Mempengaruhi Prestasi Belajar Mahasiswa (Studi pada mahasiswa Jurusan Akuntansi Politeknik Negeri Pontianak). Jurnal EKSOS, $8(1), 19-25$.

Rukmana, A., \& Suryana, A. (2006). Pengelolaan Kelas. Bandung: UPI PRESS.

Ruswahyuningsih, M., \& Afiatin, T. (2015). Resiliensi pada Remaja Jawa. Gadjah Mada Journal of Psychology, 1(2), 96-105. Diambil kembali dari http://download.portalgaruda.org/article.php?article=343127\&val=7991\&title=R esiliensi\%20pada\%20Remaja\%20Jawa

Setyabudi, I., Nuraini, Alfian, R., \& Nailufar, B. (2017). Konsep Taman Edukasi pada Sekolah Dasar di Kota Malang (Studi Kasus: SDN Lowokwaru 3 Malang). Jurnal RUAS, 15(1), 23-34.

Shannon, G. S., \& Bylsma, P. (2007). Nine Characteristics of High-Performing Schools: A research-based resource for schools and districts to assist with improving student (2nd ed.). Olympia, WA: OSPI.

Silva, L. T., Oliveira, I. S., \& Silva, J. F. (2016). The impact of urban noise on primary schools. Perceptive evaluation and Objective Assessment. Applied Acoustics, 106(2016), 2-9. doi:10.1016/j.apacoust.2015.12.013

Slameto. (2010). Belajar dan Faktor-faktor yang Mempengaruhinya. Jakarta: Rineka Cipta.

Sobri, K. M., Hanum, F., Zulnaidi, H., \& Alfitri. (2017). A comparative study of school environment for students' skills development in Malaysia and Indonesia. Kasetsart Journal of Social Sciences, $x(\mathrm{x}), \mathrm{x}-\mathrm{x}$. doi:10.1016/j.kjss.2017.10.002

Suharyat, Y. (2009). Hubungan Antara Sikap, Minat dan Perilaku Manusia. REGION, 1(3), 1-19. Diambil kembali dari http://download.portalgaruda.org/article.php?article=19324\&val=1225

Sukmadinata, N. S. (2009). Landasan Psikologi Proses Pendidikan. Bandung: Remaja Rosdakarya.

Tucker, R., \& Izadpanahi, P. (2017). Live green, think green: Sustainable school architecture and children's environmental attitudes and behaviors. Journal of Environmental Psychology, 51(2017), 209-216. doi:10.1016/j.jenvp.2017.04.003

Wang, D., Jiang, J., Liu, Y., Wang, Y., Xu, Y., \& Liu, J. (2017). Student responses to classroom thermal environments in rural primary and secondary schools in winter. Building and Environments, 115(2017), 104-117. doi:10.1016/j.buildenv.2017.01.006 